\title{
Solubilization of the Apamin Receptor Associated with a Calcium-Activated Potassium Channel from Rat Brain
}

\author{
Michael J. Seagar, Béatrice Marqueze, and Francois Couraud \\ INSERM U172-UA 1179, Laboratoire de Biochimie, Faculté de Médecine, 13326 Marseille Cedex 15, France
}

\begin{abstract}
The apamin binding protein was solubilized from rat brain synaptic membranes using sodium cholate. Receptor yield and stability depended closely on the detergent/protein ratlo. In optimum conditions the receptor retained high affinity for mono ${ }^{125}$-iodoapamin with $K_{d}=\mathbf{4 0} \mathrm{pM}$ at pH 7.5 and $1^{\circ} \mathrm{C}$ and a binding capacity of $17 \mathrm{fmol} / \mathrm{mg}$ protein. ${ }^{25}$ l-apamin binding was stimulated by $K^{+}$ions with a $K_{0.5}=0.6 \mathrm{~mm}$, demonstrating that the regulatory $\mathrm{K}^{+}$site is also part of the soluble complex. Other ions could be substituted for $\mathrm{K}^{+}$with an affinity sequence $\mathrm{TI}^{+}=\mathrm{K}^{+}=\mathrm{Rb}^{+}>\mathrm{Cs}^{+}>\mathrm{NH}_{4}{ }^{+}>\mathrm{Li}^{+}$or $\mathrm{Na}^{+}$. Binding was inhibited by the neuromuscular blockers gallamine and tubocurarine and by the $K^{+}$channel blockers quinidine and tetraethylammonium chloride but not by 4-aminopyridine, in agreement with known pharmacological profile for inhibition of apamin-sensitive $K^{+}$permeability. Increasing the $\mathrm{K}^{+}$concentration did not reverse inhibition by tetraethylammonium ions demonstrating that it does not bind competitively to the regulatory cationic site. Analysis of the covalently labeled apamin binding protein/sodium cholate complex by density gradient centrifugation indicated a high molecular weight with $S_{20, w}=20 \mathrm{~S}$.
\end{abstract}

Potassium channels fulfill a variety of physiological functions in electrically excitable cells. They are involved in setting resting potential, repolarizing and hyperpolarizing the membrane, and modulating firing frequency (Hille, 1984). $\mathrm{K}^{+}$channels may be gated by membrane potential, binding of a neurotransmitter or cytoplasmic $\mathrm{Ca}^{2+}$ levels. Although a wide variety of $\mathrm{K}^{+}$channel types has been described by biophysical techniques, very little is known of their structure at a molecular level.

Apamin, a peptide neurotoxin from bee venom, blocks the $\mathrm{Ca}^{2+}$-activated $\mathrm{K}^{+}$current responsible for the slow hyperpolarization that follows the action potential of certain neurons (Hugues et al., 1982a; Pennefather et al., 1985). High-affinity, low-capacity receptors for ${ }^{125}$ I-apamin have been detected both in membrane preparations (Habermann and Fisher, 1979; Hugues et al., 1982b) and in intact primary cultured neurons (Seagar et al., 1984) from rat brain, and this ligand therefore is a potentially useful probe for the biochemical characterization of the binding protein that is closely associated with or constitutes a type of $\mathrm{K}^{+}$channel.

Received Apr. 10, 1986; revised June 16, 1986; accepted July 23, 1986.

This work was supported by the Institut National de la Santé et de la Recherche Médicale (U 172) and the Centre National de la Recherche Scientifique (UA 1179). We wish to thank Christian Leveque for technical assistance and Catherine LabbéJullie and Brigitte Ceard for purifying the apamin used in this study.

Correspondence should be addressed to M. J. Seagar, INSERM U172-CNRS UA 1179, Laboratoire de Biochimie, Faculté de Médicine, Secteur Nord, Boulevard Pierre Dramard, 13326 Marseille Cedex 15, France.

Copyright (C) 1987 Society for Neuroscience $0270-6474 / 87 / 020565-06 \$ 02.00 / 0$
Covalent labeling techniques and radiation inactivation have allowed the identification of the membrane polypeptides, considered to be putative $\mathrm{K}^{+}$channel subunits, which form the receptor site (Schmid-Antomarchi et al., 1984; Seagar et al., $1985,1986)$. However, further analysis of the apamin binding protein and confirmation that it alone constitutes a $\mathrm{K}^{+}$channel will require detergent extraction, purification, and reconstitution of the appropriate ion conducting properties. In this report we describe the solubilization of the active apamin receptor from rat brain synaptic membranes. The extracted receptor remains associated with the regulatory $\mathrm{K}^{+}$binding site (Habermann and Fisher, 1979; Hugues et al., 1982b; Seagar et al., 1984) and retains the pharmacological characteristics of this type of $\mathrm{Ca}^{2+}$ activated $\mathrm{K}^{+}$channel (Cook and Haylett, 1985).

\section{Materials and Methods}

Materials. Apamin, isolated from bee venom (Banks et al., 1981), was purified by high-pressure liquid chromatography, amino acid analysis, and toxicity testing. The peptide was radioiodinated (Amersham Corp.) at $\mathrm{His}_{18}$ (Seagar et al., 1984), and a mono ${ }^{125}$ I-iodoapamin derivative with a specific radioactivity of $2000 \mathrm{Ci} / \mathrm{mmol}$ was separated by $\mathrm{SP}$ (sulfopropyl) Sephadex C-25 (Pharmacia) chromatography (Hugues et al., 1982b).

Gallamine, thyroglobulin, and lactoperoxidase were from Sigma, tetraethylammonium chloride (TEA) and 4-aminopyridine from Merck, $d$-tubocurarine from Fluka, verapamil and D600 from Knoll, trifluoperazine from Smith Kline and French, and catalase from Boehringer.

Membrane preparation and solubilization. Lysed synaptosomal membranes $\left(\mathrm{P}_{3} \mathrm{~L}\right)$ were prepared essentially according to a modification (Hartshorne and Catterall, 1984) of the Gray and Whittaker method (Gray and Whittaker, 1962). Decerebellate brains from Wistar rats were homogenized in $0.32 \mathrm{~m}$ sucrose, $10 \mathrm{~mm}$ Tris, $5 \mathrm{~mm} \mathrm{KCl}$ adjusted to $\mathrm{pH}$ 7.5 with $\mathrm{HCl}$, at $10 \%$ (wt/vol) using a Thomas $\mathrm{C}$ glass/Tefion apparatus. The $27,000 \times g$ pellet of a postnuclear supernatant $\left(\mathrm{P}_{3}\right)$ was lysed by resuspension in $5 \mathrm{~mm}$ Tris, $5 \mathrm{~mm} \mathrm{KCl,} 1 \mathrm{~mm}$ EDTA, adjusted to $\mathrm{pH}$ 8.2 with $\mathrm{HCl}$ ( $3 \%$ initial brain wet weight/lysis buffer volume). After $30 \mathrm{~min}$ at $1^{\circ} \mathrm{C}$, the lysed membranes were sedimented $\left(\mathrm{P}_{3} \mathrm{~L}\right)$ for $40 \mathrm{~min}$ at $27,000 \times g$ and resuspended at about $1 \mathrm{gm}$ initial brain wet weight/ $\mathrm{ml}$ in lysis buffer containing the protease inhibitors phenylmethylsulfonyl fluoride $(0.1 \mathrm{~mm})$, iodoacetamide $(1 \mathrm{~mm}), 1-10$-phenanthroline (1 $\mathrm{mM})$, pepstatin A $(1 \mu \mathrm{M})$, and EDTA (1 mM). Membranes were stored in liquid nitrogen prior to solubilization. In certain experiments the effects of cations were tested by substituting $\mathrm{NaCl}$ for $\mathrm{KCl}$ and omitting EDTA during preparation.

Detergent was added from a concentrated stock solution to defrozen $\mathrm{P}_{3} \mathrm{~L}$ membranes to obtain the required final concentration $(5 \% \mathrm{wt} / \mathrm{vol}$ sodium cholate in the standard conditions) with a membrane protein concentration of $20 \mathrm{mg} / \mathrm{ml}$. After incubation, with intermittent mixing, at $1^{\circ} \mathrm{C}$ for $30 \mathrm{~min}$ insoluble material was sedimented at $160,000 \times g$ for $40 \mathrm{~min}$. Protein was assayed by a modified Lowry method (Lowry et al., 1951) using a BSA standard.

${ }_{125} I$-apamin binding assay. Detergent extracts, usually 20-30 $\mu$ l (i.e., about $400 \mu \mathrm{g}$ protein) of the $160,000 \times g$ supernatant, were incubated with ${ }^{125} \mathrm{I}$-apamin in $0.5 \mathrm{ml}$ of a buffer containing $0.3 \%$ sodium cholate, $25 \mathrm{~mm}$ Tris, $10 \mathrm{mM} \mathrm{KCl}$, and $0.1 \%$ serum albumin adjusted to $\mathrm{pH} 7.5$ 

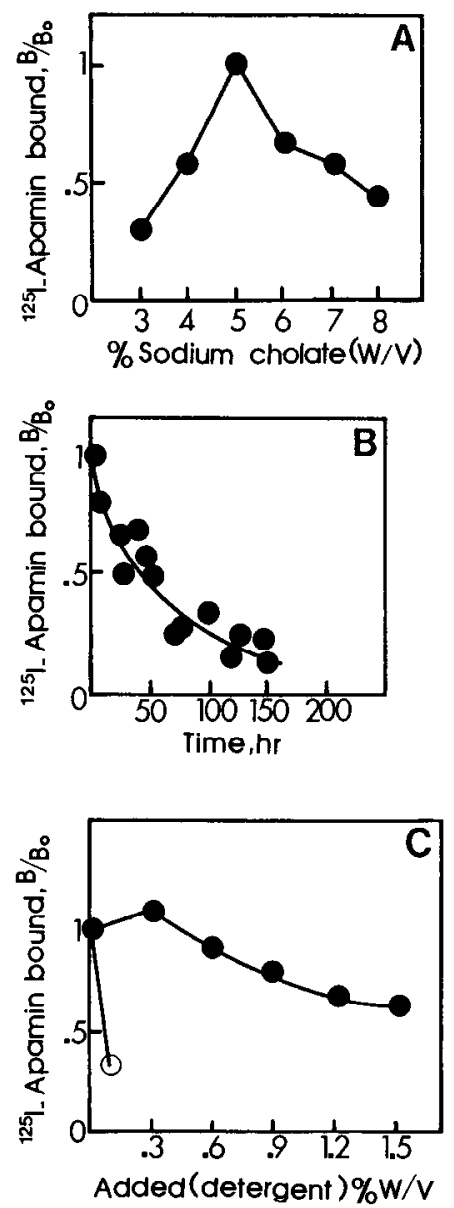

Figure 1. Solubilization and stability of apamin binding sites. $A$, Synaptic membranes $(20 \mathrm{mg}$ protein $/ \mathrm{ml}$ ) were extracted with increasing sodium cholate concentrations for $30 \mathrm{~min}$ at $1^{\circ} \mathrm{C}$. After high-speed centrifugation, the solubilized receptor present in the supernatant was assayed as described in Materials and Methods. Binding assays contained 200 pM ${ }^{125}$ I-apamin in the absence (total binding) or presence (nonspecific binding) of $0.1 \mu \mathrm{M}$ unlabeled apamin; subtraction gave the specific binding. $B$, bound; $B_{0}$, bound after extraction with $5 \%$ sodium cholate. $B$, Synaptic membranes were extracted with $5 \%$ sodium cholate, and solubilized material was maintained at $1{ }^{\circ} \mathrm{C}$. Receptor binding activity was assayed at the indicated times after solubilization. $B$, bound; $B_{0}$, bound at $t=0 . C$, After extraction in $5 \%$ sodium cholate, portions of solubilized material were diluted into 20 vol of binding buffer containing the indicated concentrations of sodium cholate $(\Theta)$ or Triton $\mathrm{X}-100(\mathrm{O})$. Receptor binding activity was assayed after $1 \mathrm{hr}$ at $1^{\circ} \mathrm{C} . \mathrm{B}$, bound; $B_{0}$, bound in the absence of any added detergent.

with $\mathrm{HCl}$ at $1^{\circ} \mathrm{C}$ for the indicated times. Bound ligand was separated by rapid filtration over glass fiber (Whatman $\mathbf{G F} / \mathbf{B}$ ) filters pretreated with the polycation polyethyleneimine in $0.3 \%$ aqueous solution. With this technique, introduced by Bruns et al. (1983) acidic membrane proteins are electrostatically retained, whereas neutral or basic ligands such as apamin are not. After washing filters 3 times with $2 \mathrm{ml}$ buffer in less than $20 \mathrm{sec}$, bound ligand was measured by gamma counting with $60 \%$ efficiency. Nonspecific binding was determined in the presence of 0.1 $\mu \mathrm{M}$ native apamin and subtracted from total binding to give the specific component.

In experiments to determine the effects of monovalent cations, ionic strength was maintained at a constant level by substitution for $\mathrm{NaCl}$. All cations were used as chloride salts with the exception of $\mathrm{Tl}^{+}$, which was used as a nitrate in a Tris-HEPES buffer to avoid the precipitation of insoluble $\mathrm{TICl}$. In this case, the reference compound was $\mathrm{NaNO}_{3}$.

Density gradient centrifugation. Membranes were covalently labeled with ${ }^{125}$ I-5-azido-,2-nitrobenzoate (ANB)-apamin by a previously reported technique (Seagar et al., 1985, 1986), and then washed and solubilized following the standard protocol in $5 \%$ sodium cholate; 0.5
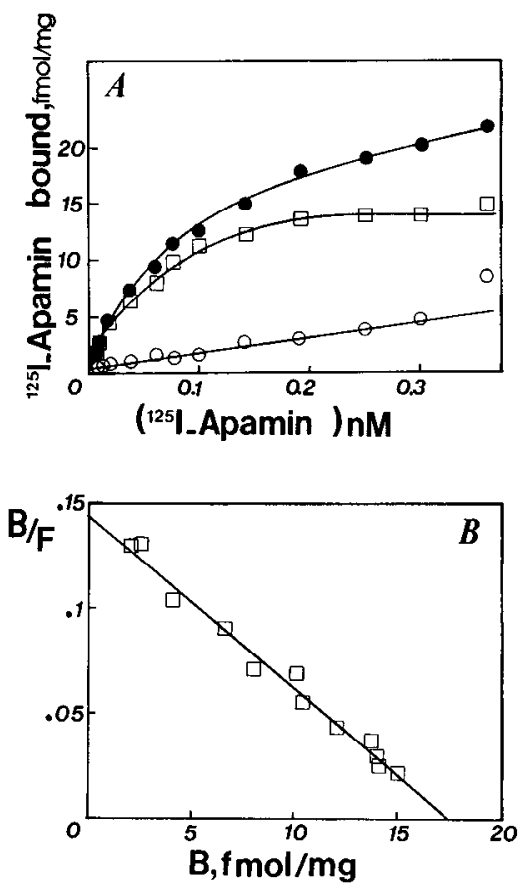

Figure 2. Equilibrium binding to sodium cholate solubilized apamin receptors. $A$, Solubilized material was incubated with increasing concentrations of ${ }^{125} I$-apamin in the absence $(O)$ and presence $(O)$ of 0.1 $\mu \mathrm{M}$ unlabeled apamin for $100 \mathrm{~min}$ at $1^{\circ} \mathrm{C}$. Bound radioactivity was then measured by a rapid filtration assay as described in Materials and Methods. The saturable specific binding component $(\square)$ was calculated by subtraction of nonspecific binding $(\mathrm{O})$ from total binding $(\bullet)$. $B$, Scatchard plot of specific binding: $B$, bound (fmol/ $\mathrm{mg}$ protein); $F$, free.

$\mathrm{ml}$ of the $160,000 \times \mathrm{g}$ supernatant was layered over a $12.5 \mathrm{ml} \mathrm{5-20 \%}$ linear sucrose gradient formed in $1 \%$ sodium cholate, $50 \mathrm{~mm} \mathrm{KCl,} 25$ mм Tris, $1 \mathrm{~mm}$ EDTA adjusted to $\mathrm{pH} 9$ with $\mathrm{HCl}$. Gradients were centrifuged at $30,000 \mathrm{rpm}$ for $15 \mathrm{hr}$ in a Beckman SW 40 rotor. The standard proteins lactoperoxidase (5.2 S) and catalase $(11.3 \mathrm{~S})$ were detected by absorbance at $420 \mathrm{~nm}$ and thyroglobulin (19.2 S) by absorbance at $280 \mathrm{~nm}$.

\section{Results}

\section{Solubilization and stability of the apamin binding protein}

Preliminary experiments showed that the apamin receptor could be solubilized from a crude rat brain synaptic membrane fraction $\left(\mathrm{P}_{3} \mathrm{~L}\right)$ using the charged steroidal detergents sodium cholate, sodium deoxycholate, or 3-(3-cholamidopropyl)dimethylammonio-1-propane sulfonate (CHAPS). Rapid gel filtration over Sephadex G-50, polyethylene glycol precipitation, and vacuum filtration through polyethyleneimine-treated glass fiber filters all allowed separation of receptor-bound ligand. The latter was then systematically used, as it proved more rapid than gel filtration and gave lower levels of nonspecific binding than polyethylene glycol precipitation.

The relatively low receptor capacity of the starting material (about $30 \mathrm{fmol} / \mathrm{mg}$ protcin) led us to standardize solubilization conditions at a high membrane protein concentration $(20 \mathrm{mg} /$ $\mathrm{ml}$ ). As shown in Figure $1 A$, treatment with a range of sodium cholate concentrations indicated a clear optimum at $5 \% \mathrm{wt} / \mathrm{vol}$. Under these conditions about $30 \%$ of the initial membrane receptor content was recovered in an active soluble form. This is probably an underestimation of the true solubilization yield as it was in practice impossible to retrieve the $160,000 \times g$ supernatant completely, and some soluble material remained as- 

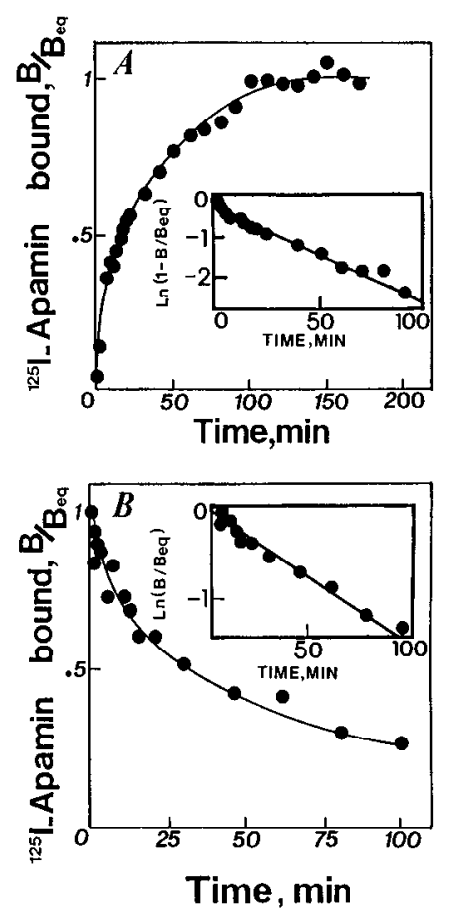

Figure 3. Kinetics of binding to the solubilized apamin receptor. $A$, Solubilized material was incubated with $100 \mathrm{pm}{ }^{125} \mathrm{I}$-apamin at $1^{\circ} \mathrm{C}$; specifically bound radioactivity was determined at the indicated times. $B$, At equilibrium, dissociation was initiated by addition of $0.1 \mu \mathrm{M}$ unlabeled apamin, and the remaining specifically bound radioactivity was determined at the indicated times. Insets: Semilogarithmic plots of kinetic data. $B$, bound; $B_{\text {eq }}$, bound at equilibrium.

sociated with the loosely attached upper layer of the pellet. Receptors were considered to be soluble based on the criteria of nonsedimentability at $160,000 \times g$ for 40 min and lack of retention on a filter of $0.2 \mu \mathrm{m}$ pore diameter.

Receptor binding activity decayed with a half-life of about 50 $\mathrm{hr}$ in an extract maintained at $1{ }^{\circ} \mathrm{C}$ (Fig. $1 B$ ). No binding was observed after membrane dissolution in the nonionic detergents Triton X-100 or Lubrol-PX. The stability to treatment with various detergents after the initial solubilization in $5 \%$ sodium cholate is shown in Figure 1C. Specific binding was lost as detergent concentration was increased. Considerable inactivation occurred after $1 \mathrm{hr}$ in $0.1 \%$ Triton X-100, whereas the receptor was relatively stable over a larger concentration range in sodium cholate.

\section{Binding parameters of the solubilized apamin receptor}

The results of a typical equilibrium binding experiment demonstrating saturable specific binding are shown in Figure $2 A$. A Scatchard plot of the data (Fig. 2B) indicated a single class of high-affinity sites with $K_{d}^{*}=63 \mathrm{pM}$ and $B_{\max }=17 \mathrm{fmol} / \mathrm{mg}$ protein at $\mathrm{pH} 7.5$ and $1^{\circ} \mathrm{C}$. Average values obtained from several identical experiments were $K_{d}{ }^{*}=40 \mathrm{pM}$ and $B_{\max }=17 \mathrm{fmol} /$ $\mathrm{mg}$. The receptor capacity was thus about half that of the original membrane preparation. The $K_{d}$ of native apamin was determined by displacement of ${ }^{125} \mathrm{I}$-apamin (see Fig. S). Fifty percent displacement was obtained at $28 \mathrm{pm}\left(K_{0.5}\right)$, which by substitution into the equation $K_{0.5}=K_{d}\left(1+\left[{ }^{125}\left[\right.\right.\right.$-apamin] $\left./{ }^{*} K_{d}\right)$ gave $K_{d}=20$ pM at $\mathrm{pH} 7.5$ and $1^{\circ} \mathrm{C}$.

Association and dissociation kinetics are represented in Figure 3. The slopes of the linear semilogarithmic plots gave $k_{\mathrm{app}}$
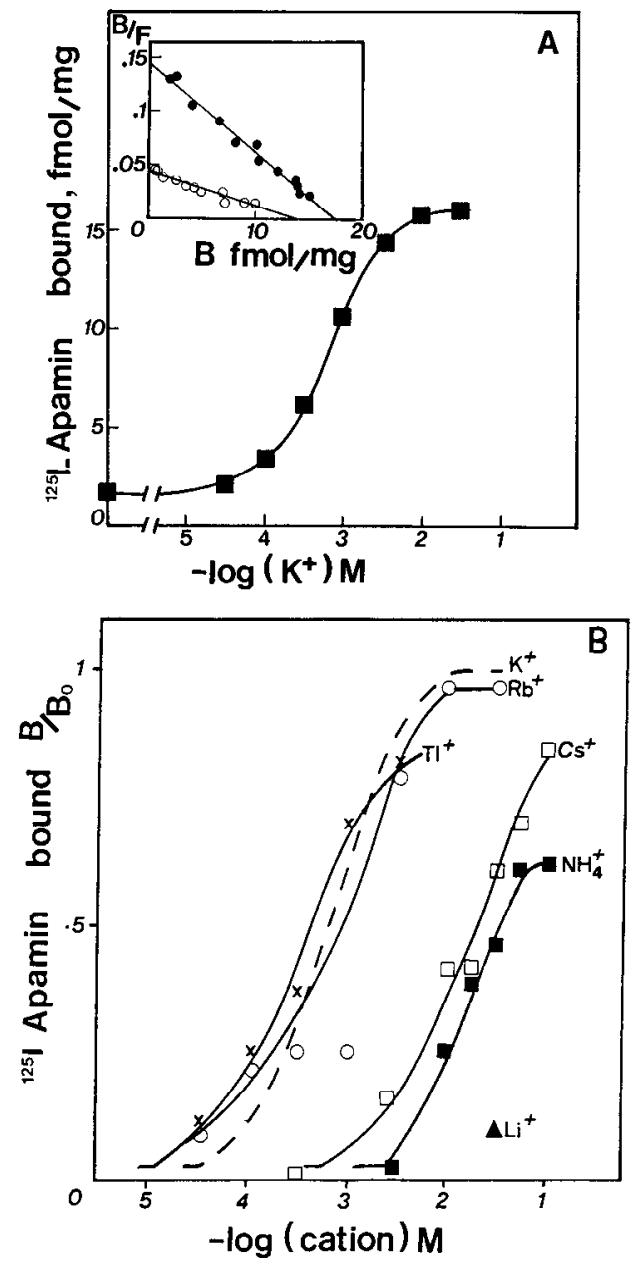

Figure 4. Effects of cations on ${ }^{125}$ I-apamin binding to solubilized receptors. $A$, Solubilized material was incubated with 200 pM ${ }^{125}$ I-apamin in the presence of the indicated concentrations of $\mathrm{K}^{+}$. Salt concentration was maintained at a constant level throughout $(30 \mathrm{~mm})$ by gradually substituting $\mathrm{KCl}$ for $\mathrm{NaCl}$. Specific binding was assayed after $100 \mathrm{~min}$ at $1^{\circ} \mathrm{C}$. Inset: Scatchard plot of ${ }^{125} \mathrm{I}$-apamin saturation curves determined at $0.3 \mathrm{~mm}(0)$ and $10 \mathrm{~mm}(0) \mathrm{KCl} . B$, bound; $F$, free. $B$, Experiments were carried out as in $A$ with $\mathrm{Tl}^{+}(\mathrm{x}), \mathrm{Rb}^{+}(\mathrm{O}), \mathrm{Cs}^{+}(\square), \mathrm{NH}_{4}{ }^{+}(\square)$, and $\mathrm{Li}^{+}(\Delta)$. The dashed line represents the data obtained with $\mathrm{K}^{+}$in $A$. Ionic strength was maintained at a constant level by substituting test ions for $\mathrm{Na}^{+}$. All cations were added as chlorides with the exception of $\mathrm{Tl}^{+}$(see Materials and Methods). $B$, bound; $B_{0}$, bound in $30 \mathrm{mM} \mathrm{KCl}$.

and $k_{d}$, which, using the equation $k_{\text {app }}=k_{a}\left[{ }^{[25}\right.$ I-apamin] $+k_{d}$, allowed calculation of $k_{a}$.

The rate constants were $k_{a}=1.5 \times 10^{6} \mathrm{M}^{-1} \mathrm{sec}^{-1}$ and $k_{d}=$ $2.2 \times 10^{-4} \mathrm{sec}^{-1}$; these gave $K_{d}=k_{d} / k_{a}=147 \mathrm{pM}$, in reasonable agreement with the determination at equilibrium.

\section{Ionic regulation of apamin binding}

${ }^{125}$ I-apamin binding to cultured neurons (Seagar et al., 1984) and brain membranes (Habermann and Fisher, 1979; Hugues et al., 1982a, b) requires the presence of $\mathrm{K}^{+}$ions. Experiments were carried out to determine whether this modulatory effect was retained after detergent extraction of the binding protein. Increasing the $\mathrm{K}^{+}$concentration between 0.1 and $10 \mathrm{~mm}$ at constant ionic strength led to an 8-fold increase in specific binding with $50 \%$ stimulation at $0.6 \mathrm{~mm} \mathrm{~K} \mathrm{~K}^{+}$(see Fig. $4 A$ ). Scatchard plots of saturation curves established at 0.3 and $10 \mathrm{~mm} \mathrm{~K}$ indicated a clear effect on apamin receptor affinity (inset to Fig. 


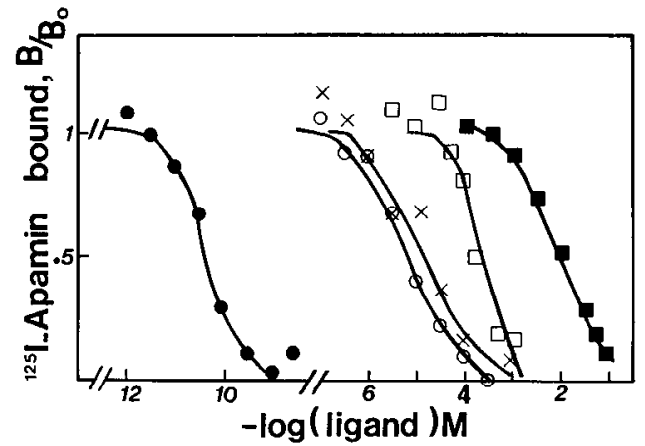

Figure 5. Inhibition of ${ }^{125} \mathrm{I}$-apamin binding to solubilized receptors by neuromuscular and potassium channel blockers. Solubilized material was incubated with $15 \mathrm{pM}^{125} \mathrm{I}$-apamin in the presence of apamin (O), gallamine $(0)$, tubocurarine $(\times)$, quinidine $(\square)$, and tetraethylammonium chloride $\left(\square\right.$ ). Specific binding was assayed after $100 \mathrm{~min}$ at $1^{\circ} \mathrm{C}$. In the experiment with tetraethylammonium chloride, the ionic strength was maintained at a constant level by substitution for $\mathrm{NaCl}$. $B$, bound; $B_{0}$, bound in the absence of competing ligand.

$4 A$ ). As shown in Figure $4 B$, other cations may be substituted for $\mathrm{K}^{+}$with an affinity series of $\mathrm{K}^{+}=\mathrm{Tl}^{+}=\mathrm{Rb}^{+}>\mathrm{Cs}^{+}>$ $\mathrm{NH}_{4}^{+}>\mathrm{Li}^{+}$and the reference ion $\mathrm{Na}^{+}$.

\section{Effects of neuromuscular and ion channel blockers}

In keeping with a recent report on the pharmacological profile for inhibition of the apamin-sensitive $\mathrm{Ca}^{2+}$-activated $\mathrm{K}^{+}$permeability in hepatocytes (Cook and Haylett, 1985), gallamine and tubocurarine displaced ${ }^{125}$ I-apamin with calculated $K_{i}$ values of 5 and $10 \mu \mathrm{M}$, respectively (Fig. 5)-about $10^{5}$ times less potcnt than apamin itself. The $\mathrm{K}^{+}$channel blockers quinidine $\left(K_{i}=0.2 \mathrm{~mm}\right)$ and $\mathrm{TEA}^{+}\left(K_{i}=6 \mathrm{~mm}\right)$ were less potent, whereas $10 \mathrm{~mm}$ 4-aminopyridine was completely inactive. All the binding inhibition curves, with one exception, were complete over $2 \log$ of concentration with a Hill coefficient close to 1 , compatible with simple competition for a single class of receptor site. Displacement by quinidine occurred with a Hill coefficient of 2 , suggesting positive cooperativity.

Experiments were carried out to determine whether the inhibitory action of $\mathrm{TEA}^{+}$could be due to competition with $\mathrm{K}^{+}$ ions at the stimulatory cationic site. As shown in Table 1, increasing the $\mathrm{K}^{+}$concentration 10 -fold at constant ionic strength did not reverse inhibition by $\mathrm{TEA}^{+}$.

Neither the calcium antagonists verapamil and D-600 $(10 \mu \mathrm{M})$ nor the calmodulin inhibitor trifluoperazine $(10 \mu \mathrm{M})$ had any effect on ${ }^{125} \mathrm{I}$-apamin binding.

Table 1. Lack of competition of TEA with $\mathrm{K}^{+}$per binding to the regulatory site

\begin{tabular}{lll} 
Incubation conditions & $\begin{array}{l}\text { 125I-apamin bound } \\
(\mathrm{fmol} / \mathrm{mg} \text { protein } \pm \\
\mathrm{SD}, n=3)\end{array}$ & $\begin{array}{l}\text { Percent } \\
\text { of } \\
\text { control }\end{array}$ \\
\hline $5 \mathrm{mM} \mathrm{K}^{+}$ & $9.6 \pm 0.1$ & 100 \\
$50 \mathrm{mM} \mathrm{K}^{+}$ & $9.3 \pm 0.5$ & 97 \\
$5 \mathrm{mM} \mathrm{K}^{+}, 30 \mathrm{mM} \mathrm{TEA}^{+}$ & $3.3 \pm 0.6$ & 34 \\
$50 \mathrm{mM} \mathrm{K}^{+}, 30 \mathrm{mM} \mathrm{TEA}^{+}$ & $3.7 \pm 0.9$ & 38
\end{tabular}

Detergent extracts were incubated with $100 \mathrm{pm}^{125 \mathrm{I}-a p a m i n}$ for $100 \mathrm{~min}$ at $1{ }^{\circ} \mathrm{C}$ in the above conditions. The final salt concentration in each case was adjusted to $100 \mathrm{~mm}$ by addition of $\mathrm{NaCl}$. Nonspecific binding determined in the presence of $0.1 \mu \mathrm{M}$ native apamin was subtracted from total binding to give the specific component.

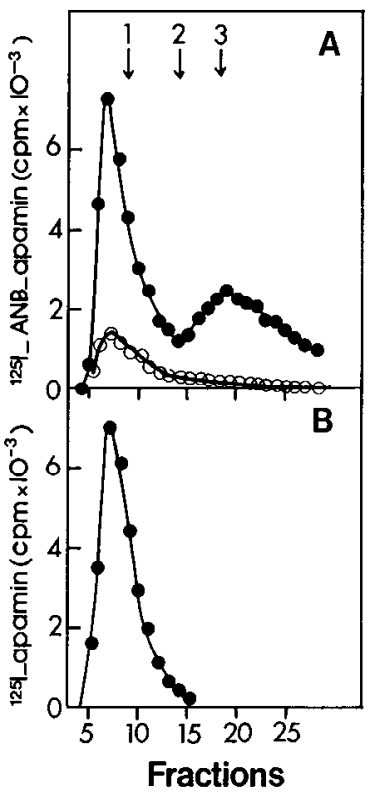

Figure 6. Sedimentation analysis of the solubilized apamin receptor. $A$, Synaptic membranes were covalently labeled with 30 pM ${ }^{125}$ I-ANBapamin in the absence (O) and presence $(O)$ of $50 \mathrm{nM}$ unlabeled apamin. After the standard solubilization procedure, high-speed supernatants were layered over $5-20 \%$ sucrose gradients containing $1 \%$ sodium cholate. Centrifugation was carried out as described in Materials and Methods. The migration positions of standard proteins indicated by the $a r$ rows are as follows: 1, lactoperoxidase (5.2 S); 2, catalase (11.3 S); and 3 , thyroglobulin (19.2 S). $B$, Parallel gradient contained $10 \mathrm{fmol}{ }^{125} \mathrm{I}-$ apamin in the absence of solubilized receptor to indicate the migration position of the free ligand.

\section{Sucrose gradient centrifugation}

Sedimentation analysis was carried out in 5-20\% linear gradients formed in buffers containing $1 \%$ sodium cholate. In preliminary experiments, attempts were made to detect the receptor by direct binding. However, exposure of the solubilized receptor to solutions containing $1 \%$ sodium cholate for the time necessary to achieve satisfactory resolution by density gradient centrifugation led to a loss in binding activity to a level at which reproducible detection was impossible. For this reason we chose to label membrane receptors covalently using ${ }^{125}$ I-ANB-apamin and then, after following the standard solubilization protocol, subject the extract to sedimentation analysis in gradients containing marker protcins of known $S_{20, w}$.

Two radioactive peaks were resolved (Fig. 6). The peak near the top of the gradient comigrated with ${ }^{125} \mathrm{I}$-apamin and thus represents free ${ }^{125}$ I-ANB-apamin. As covalent labeling only occurs with about $40 \%$ efficiency (Seager et al., 1985), $60 \%$ of the receptor-bound ${ }^{125}$ I-ANB-apamin was consequently free to dissociate. The second peak sedimented at a similar rate to thyroglobulin and is thought to be the receptor-sodium cholate complex. The sedimentation coefficient was estimated to be 20 $S$ by linear extrapolation. When receptor sites were protected by $50 \mathrm{~nm}$ native apamin, the $20 \mathrm{~S}$ peak disappeared completely. Blocking specific binding with native apamin also reduced the free ${ }^{125}$ I-ANB-apamin peak, as the component that dissociates from receptors was no longer present. A similar phenomenon occurs at the migration front when photoaffinity-labeled membranes are analyzed by SDS-PAGE (cf. Seagar et al., 1985, 1986). 


\section{Discussion}

An essential step in membrane protein characterization is extraction of a biologically active and stable, soluble detergentprotein complex. Solubilization with a reasonably good yield is also crucial in the case of the apamin binding protein because of its very low density in the initial membrane preparations. Its main interest lics in the fact that this protcin is associated with or constitutes a type of $\mathrm{K}^{+}$channel, and biochemical knowledge in this field has been severely limited by a general lack of specific ligands to use as probes.

A previous report by Schmid-Antomarchi et al. (1984) described the detection of high-affinity ${ }^{125}$ I-apamin binding to sodium cholate and CHAPS extracts of rat brain membranes. Very low receptor yields were obtained ( $<1 \mathrm{fmol} / \mathrm{mg}$ protein) with poor stability (half-life $<2 \mathrm{hr}$ ), and no data on ionic or pharmacological modulation of binding or the size of the soluble complex were reported. The protocol described in the present paper allows the solubilization of the apamin binding protein in a form that retains all of the essential binding properties that have been demonstrated with intact cells (Seagar et al., 1984; Cook and Haylett, 1985) or membrane preparations (Habermann and Fisher, 1979; Hugues et al., 1982a, b). Only charged steroidal detergents were effective, and sodium cholate was chosen for the standard procedure, with which at least $30 \%$ of membrane receptors were released in a soluble active form.

The soluble binding protein retained very high affinity for ${ }^{125}$ I-apamin, with a $K_{d}=40 \mathrm{pM}$ compared to $K_{d}=30 \mathrm{pm}$ for the membrane-bound form of this receptor. The average binding capacity obtained was $17 \mathrm{fmol} / \mathrm{mg}$ protein.

Although binding site density is very low, enrichment by affinity chromatography can be envisaged and receptor stability (half-life $=50 \mathrm{hr}$ ) is now compatible with this approach.

The basic solubilization protocol used was similar to that described by Schmid-Antomarchi et al. (1984). The much improved yield and stability can probably be attributed to careful control of the detergent/protein ratio, which shows a sharp optimum, the inclusion of a wider spectrum of protease inhibitors, and use of a rapid receptor assay based on vacuum filtration, which minimizes ligand dissociation during separation.

It is not yet established whether apamin blocks the $\mathrm{Ca}^{2+}$. dependent $\mathrm{K}^{+}$current by binding to the ion channel itself or to an associated regulatory component. Two rather indirect arguments can be proposed in favor of the first hypothesis. First, ${ }^{125}$ I-apamin binding to intact neurons (Seagar et al., 1984) and to brain membranes (Habermann and Fisher, 1979; Hugues et al., 1982b) is stimulated by occupation of a $\mathrm{K}^{+}$ion binding site that saturates at low millimolar concentrations. It is reasonable to assume that this $\mathrm{K}^{+}$-selective site is physiologically relevant to and thus physically associated with the ion-permeation pathway, implying, in turn, that the apamin receptor site is also closely linked to the $\mathrm{K}^{+}$channel. Second, the classical $\mathrm{K}^{+}$channel blockers quinidine and $\mathrm{TEA}^{+}$displace ${ }^{125} \mathrm{I}$-apamin from its binding site and inhibit the $\mathrm{Ca}^{2+}$-activated $\mathrm{K}^{+}$permeability in the same concentration range (Seagar et al., 1984; Cook and Haylett, 1985).

It was important therefore to determine whether the solubilized receptor retained the same properties. ${ }^{125}$ I-apamin binding was in fact clearly dependent on the addition of $\mathrm{K}^{+}$ions demonstrating that detergent extraction does not separate the neurotoxin site from the cationic regulatory site. Whereas the effects of increasing $\mathrm{K}^{+}$concentrations on whole cells or vesicles that retain membrane potential could be interpreted as voltage-dependent binding, this cannot be the case after membrane dispersion. This observation therefore confirms the existence of a $\mathrm{K}^{+}$ion binding site tightly associated with, and probably part of, the apamin receptor protein. Scatchard analysis indicated that occupation of the $\mathrm{K}^{+}$site increased the affinity of the receptor/apamin interaction, in agreement with a report on ${ }^{125} \mathrm{I}$ apamin binding to synaptosomes (Hugues et al., 1982b).

Other cations can be substituted for $\mathrm{K}^{+}$with an affinity sequence $\mathrm{K}^{+}=\mathrm{Tl}^{+}=\mathrm{Rb}^{+}>\mathrm{Cs}^{+}>\mathrm{NH}_{4}{ }^{+}>\mathrm{Li}^{+}$or $\mathrm{Na}^{+}$. It would be interesting to compare this series with the ionic selectivity of the apamin-sensitive $\mathrm{K}^{+}$channel determined by electrophysiological methods; however, to our knowledge no data on this has yet appeared. Permeability sequences similar to this have been reported for other types of $\mathrm{K}^{+}$conductance (for review, see Hille, 1984, and Latorre and Miller, 1983), though $\mathrm{NH}_{4}{ }^{+}$is generally more permeant than $\mathrm{Cs}^{+}$, which is often an effective $\mathrm{K}^{+}$channel blocker.

A recent pharmacological study in guinea pig hepatocytes has shown that ${ }^{125} \mathrm{I}$-apamin displacement by a variety of agents correlates well with their ability to inhibit $\mathrm{Ca}^{2+}$-activated $\mathrm{K}^{+}$efflux (Cook and Haylett, 1985). Apart from apamin itself, the neuromuscular drugs tubocurarine and gallamine were the most effective, whereas the traditional $\mathrm{K}^{+}$channel blockers quinidine and $\mathrm{TEA}^{+}$were effective but less potent. These drugs are also active on the solubilized apamin receptor at concentrations similar to those reported. The results obtained with TEA ${ }^{+}$deserve further comment, as this ion is widely used for its ability to block, at millimolar concentrations, a large variety of different $\mathrm{K}^{+}$channels. It is generally believed that $\mathrm{TEA}^{+}$blocks $\mathrm{K}^{+}$channels because its diameter is the same as that of the hydrated $\mathrm{K}^{+}$ ion (Stanfield, 1983), allowing it to interact with the mouth of the ion pore itself but not to penetrate into the "selectivity filter." ${ }^{125} \mathrm{I}$-apamin is completely displaced by $\mathrm{TEA}^{+}$at constant ionic strength in a manner compatible with competitive interaction at a single class of site. Although we have not yet rigorously eliminated noncompetitive inhibition, this result suggests that ${ }^{125}$ I-apamin binds to the ion channel mouth itself. The inhibitory effect of $\mathrm{TEA}^{+}$cannot be reversed by a 10 -fold increase in $\mathrm{K}^{+}$ concentration, demonstrating that $\mathrm{TEA}^{+}$does not act by competing with $\mathrm{K}^{+}$ions for binding to the regulatory cationic site.

The apamin receptor solubilized in sodium cholate thus retains certain properties indicating that the $\mathrm{K}^{+}$channel is part of the same protein. This receptor/cholate complex has an $S_{20, \mathrm{w}}=$ 20 , which corresponds to a molecular weight of about $700 \mathrm{kDa}$; however, as much as $50 \%$ of this could be contributed by the detergent (Clarke, 1975). Photoaffinity labeling with arylazide derivatives of ${ }^{125} \mathrm{I}$-apamin has identified putative subunits of 86, 59, 33, and $22 \mathrm{kDa}$ (Seagar et al., 1985, 1986). If 1 of each type of polypeptide is present per native complex, the protein component would have a molecular weight of at least $200 \mathrm{kDa}$. However, we have no indications as to the stoichiometry of these putative subunits, and the presence of as yet unidentified additional subunits remains a possibility.

Sedimentation constants for other rat brain receptors associated with action potential ion channels have been determined. The saxitoxin receptor of the $\mathrm{Na}^{+}$channel is somewhat smaller, with an $S_{20 . w}$ of 12 in Triton X-100 (Hartshorne et al., 1980), whereas the dihydropyridine receptor associated with the voltage-dependent $\mathrm{Ca}^{2+}$ channel has a comparable $S_{20, w}$ of 19.2 in digitonin (Curtis and Catterall, 1983).

Purification of the apamin receptor to homogeneity is difficult 
to envisage. Assuming a molecular weight of $350 \mathrm{kDa}$ (i.e., $50 \%$ of that of the detergent/protein complex), a homogeneous preparation would contain $3 \mathrm{nmol}$ receptor/mg protein. As the detergent extract contains $17 \mathrm{fmol} / \mathrm{mg}$ protein, a purification factor of 200,000 would be required. This is probably impossible, even using affinity chromatography; however, considerable enrichment followed by reconstitution of a $\mathrm{Ca}^{2+}$-activated $\mathrm{K}^{+}$flux could now be attempted.

\section{References}

Banks, B. E. C., C. E. Dempsey, F. L. Pearce, C. A. Vernon, and T. E. Wholley (1981) New methods of isolating bee venom peptides. Anal. Biochem. 116: 48-52.

Bruns, R. F., K. Lawson-Wendling, and T. A. Pugsley (1983) A rapid filtration assay for soluble receptors using polyethyleneimine treated filters. Anal. Biochem. 132: 74-81.

Clarke, S. (1975) The size and detergent binding of membrane proteins. J. Biol. Chem. 250: 5459-5469.

Cook, N. S., and D. G. Haylett (1985) Effects of apamin, quinine and neuromuscular blockers on calcium activated potassium channels in guinea-pig hepatocytes. J. Physiol. (Lond.) 358: 373-394.

Curtis, B. M., and W. A. Catterall (1983) Solubilization of the calcium antagonist receptor from rat brain. J. Biol. Chem. 258: 7280-7283.

Gray, E., and V. Whittaker (1962) The isolation of nerve endings from brain: An electron microscopic study of cell fragments derived by homogeneization and centrifugation. J. Anat. 96: 79-88.

Habermann, E., and K. Fisher (1979) Bee venom neurotoxin (apamin): Iodine labeling and characterization of binding sites. Eur. J. Biochem. 94: 355-364.

Hartshorne, R. P., and W. Catterall (1984) The sodium channel from rat brain. J. Biol. Chem. 259: 1667-1695.

Hartshorne, R. P., J. Coppersmith, and W. A. Catterall (1980) Size characteristics of the solubilized saxitoxin receptor of the voltagesensitive sodium channel from rat brain. J. Biol. Chem. 255: 1057210575.

Hille, B. (1984) Potassium channels and chloride channels. In Ionic
Channels of Excitable Membranes, Sinauer Associates, Sunderland, MA.

Hugues, M., H. Schmid, G. Romey, D. Duval, C. Frelin, and M. Lazdunski (1982a) Apamin as a selective blocker of the calcium dependent potassium channel in neuroblastoma cells: Voltage clamp and biochemical characterization of the toxin receptor. Proc. Natl. Acad. Sci. USA 79: 1308-1312.

Hugues, M., D. Duval, P. Kitabgi, M. Lazdunski, and J. P. Vincent (1982b) Preparation of a pure monoiodo derivative of the bee venom neurotoxin apamin and its binding properties to rat brain synaptosomes. J. Biol. Chem. 257: 2762-2769.

Latorre, R., and C. Miller (1983) Conductivity and selectivity in potassium channels. J. Membr. Biol. 71: 11-30.

Lowry, O. M., N. J. Rosebrough, A. L. Farr, and R. J. Randall (1951) Protein measurement with the folin phenol reagent. J. Biol. Chem. 193: 265-275.

Pennefather, P., B. Lancaster, P. R. Adams, and R. A. Nicoll (1985) Two distinct $\mathrm{Ca}$ dependent $\mathrm{K}$ currents in bullfrog sympathetic ganglion cells. Proc. Natl. Acad. Sci. USA 82: 3040-3044.

Schmid-Antomarchi, H., M. Hugues, R. Norman, C. Ellory, M. Borsotto, and M. Lazdunski (1984) Molecular properties of the apamin binding component of the $\mathrm{Ca}^{2+}$ dependent $\mathrm{K}^{+}$channel. Eur. J. Biochem. 142: 1-6.

Seagar, M. J., C. Granier, and F. Couraud (1984) Interactions of the neurotoxin apamin with a $\mathrm{Ca}^{++}$activated $\mathrm{K}^{+}$channel in primary cultured neurons. J. Biol. Chem. 259: 1491-1495.

Seagar, M. J., C. Labbé-Jullié, C. Granier, J. Van Rietschoten, and F. Couraud (1985) Photoaffinity labeling of components of the apamin sensitive $\mathrm{K}^{+}$channel in neuronal membranes. J. Biol. Chem. 260: 3895-3898.

Seagar, M. J., C. Labbé-Jullié, C. Granier, A. Goll, H. Glossmann, J. Van Rietschoten, and F. Couraud (1986) Molecular structure of the rat brain apamin receptor: Differential photoaffinity labeling of putative $\mathrm{K}^{+}$channel subunits and target size analysis. Biochemistry 25 : $4051-4057$.

Stanfield, P. R. (1983) Tetraethylammonium ions and the potassium permeability of excitable cells. Rev. Physiol. Biochem. Pharmacol. 97: $1-67$. 